\title{
Performance Evaluation of a Demonstration System with PCM for Seasonal Heat Storage: Charge with Evacuated Tubular Collectors
}

\author{
Englmair, Gerald; Furbo, Simon; Kong, Weiqiang; Dannemand, Mark; Fan, Jianhua; Wang, Zhifeng
}

\section{Published in:}

Ises Solar World Congress 2017 - lea Shc International Conference on Solar Heating and Cooling for Buildings and Industry 2017, Proceedings

Link to article, DOI:

10.18086/swc.2017.13.02

Publication date:

2017

Document Version

Publisher's PDF, also known as Version of record

Link back to DTU Orbit

Citation (APA):

Englmair, G., Furbo, S., Kong, W., Dannemand, M., Fan, J., \& Wang, Z. (2017). Performance Evaluation of a Demonstration System with PCM for Seasonal Heat Storage: Charge with Evacuated Tubular Collectors. In Ises Solar World Congress 2017 - lea Shc International Conference on Solar Heating and Cooling for Buildings and Industry 2017, Proceedings International Solar Energy Society. https://doi.org/10.18086/swc.2017.13.02

\section{General rights}

Copyright and moral rights for the publications made accessible in the public portal are retained by the authors and/or other copyright owners and it is a condition of accessing publications that users recognise and abide by the legal requirements associated with these rights.

- Users may download and print one copy of any publication from the public portal for the purpose of private study or research.

- You may not further distribute the material or use it for any profit-making activity or commercial gain

- You may freely distribute the URL identifying the publication in the public portal 


\title{
Performance Evaluation of a Demonstration System with PCM for Seasonal Heat Storage: Charge with Evacuated Tubular Collectors
}

\author{
Gerald Englmair ${ }^{1}$, Simon Furbo ${ }^{1}$, Weiqiang Kong ${ }^{1}$, Mark Dannemand ${ }^{1}$, Jianhua Fan ${ }^{1}$ and \\ Zhifeng Wang ${ }^{2}$ \\ ${ }^{1}$ Department of Civil Engineering, Technical University of Denmark \\ ${ }^{2}$ Institute of Electrical Engineering, Chinese Academy of Sciences
}

\begin{abstract}
A seasonal heat storage with phase change material (PCM) for a solar space heating and domestic hot water combisystem was tested in automated operation during charge with solar collectors. A water tank was operating as buffer heat storage. Based on measurements during a representative day with sunshine, the storage system performance was evaluated regarding charge with solar heat. It shows the system behavior during typical operation resulting from the control strategy. Heat transfer rates from the solar collector array $\left(22.4 \mathrm{~m}^{2}\right.$ aperture area) to the heat stores reached a peak of $19 \mathrm{~kW}$, when PCM was melted. $30 \mathrm{kWh}$ of heat was transferred to the 7501 water volume as it heated up. Afterwards $46 \mathrm{kWh}$ of heat was transferred to the segmented PCM storage. In total $56 \%$ of the total irradiation on the tilted collector plane was utilized to heat the storage units. During PCM charge heat transfer fluid temperatures were increasing with the state of charge. This is in contrast to maximization of solar yield. However, the energy conversion efficiency (65\%) of the collector array was satisfying. By considering pump electricity consumption, an overall performance ratio of 30.8 was obtained.
\end{abstract}

Keywords: Solar combisystem; Seasonal heat storage; Demonstrator; Performance evaluation; Measurement.

\section{Introduction}

Sodium acetate trihydrate (SAT) can be utilized for heat storage in a solar combisystem for space heating and domestic hot water supply. It can be melted in sunny periods with solar heat, the PCM can cool down to the ambient temperature without solidifying and remain stable in supercooled state. The solidification can be initiated and the heat of fusion released later when heat is in demand. This concept was successfully applied to flat prototype heat storage units (Dannemand et al., 2016). SAT has a melting point of $58^{\circ} \mathrm{C}$ and a latent heat of fusion of $264 \mathrm{~kJ} / \mathrm{kg}$ (Meisingset \& Grønvold, 1984). The heat content of SAT composites was experimentally investigated by Kong et al. (2016).

A seasonal PCM heat storage demonstration system (Fig. 1) was designed based on calculations with a TRNSYS model (Dannemand et al., 2015). Four 1501 heat storage units have been assembled to a latent heat storage stack. They were tested for their ability to supercool in a stable way after being charged with a fluctuating heat source (Englmair et al., 2016). The system was built at the solar heating test facility of the Technical University of Denmark. Heat from a solar collector array, 7 panels of evacuated tubular collectors with an aperture area of $22.4 \mathrm{~m}^{2}$, was used to charge a 7501 water tank (buffer storage). The excess yield of the collector array was utilized to heat up the latent heat storage. This additional storage volume aims to preserve heat for periods with shortage of solar energy supply.
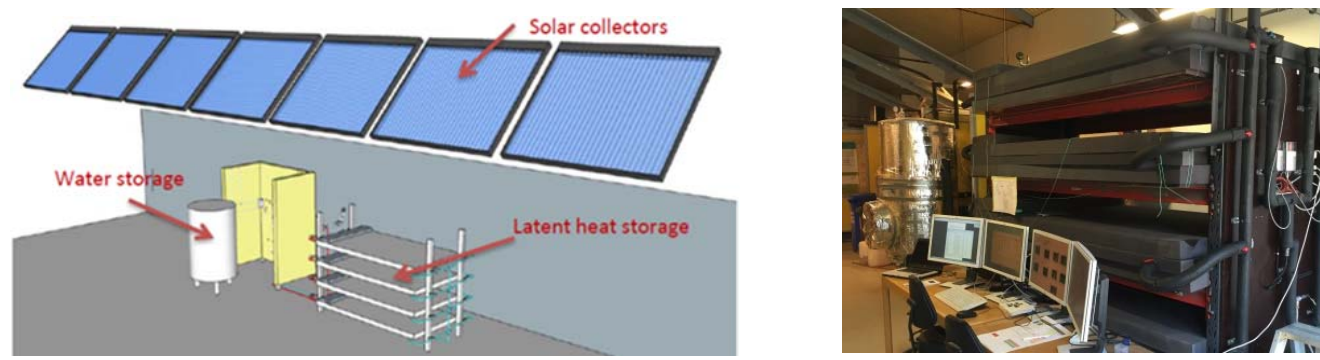

Fig. 1: Overall system design: Schematic drawing (left); Photography of water tank and PCM heat storage (right). 
Using evacuated tubular collectors as a heat source for seasonal PCM heat storage is a novel approach. The heat transfer to the buffer storage and the PCM units are of special interest, since the solar source is fluctuating and therefore an optimized control strategy has to be found. Therefore data from a sunny day $\left(9^{\text {th }}\right.$ of September 2015) where the system was operating with the designed control strategy was analyzed. The performance evaluation was based on measured heat transfer rates and monitoring of pump electricity consumption.

\begin{tabular}{|lll|}
\hline Nomenclature: & & \\
Symbol & Quantity & Unit \\
G & global irradiance & {$\left[\mathrm{W} / \mathrm{m}^{2}\right]$} \\
$\mathrm{H}$ & global irradiation & {$\left[\mathrm{Wh} / \mathrm{m}^{2}\right]$} \\
$\mathrm{P}$ & electrical power & {$[\mathrm{W}]$} \\
$\mathrm{PR}$ & performance ratio (daily) & {$[-]$} \\
$\dot{Q}$ & heat transfer rate & {$[\mathrm{W}]$} \\
Q & heat & {$[\mathrm{Wh}]$} \\
T & temperature & {$\left[{ }^{\circ} \mathrm{C}\right]$} \\
W & electrical work & {$[\mathrm{Wh}]$} \\
$\eta$ & efficiency & {$[-]$} \\
& & \\
Subscript & Quantity & \\
aperture & aperture area (collector field) & \\
charge & buffer charge and PCM charge loops \\
charge buffer & buffer charge loop & \\
charge PCM & PCM charge loop \\
coll & solar collector \\
coll loop & solar collector loop \\
P & pump \\
total & tilted surface (collector field) & \\
\hline
\end{tabular}

\section{Method}

\subsection{Hydraulic configuration}

The solar collector array was formed with 7 panels of Thermomax HP 450 (heat pipe evacuated tubular solar collectors) from Kingspan Renewables. Each panel consisted of 30 tubes. The 7 panels were connected in 2 parallel circuits. One circuit with 4 panels in series and one with 3 panels in series as illustrated in Fig 2. Equal fluid flow rate in each collector panel was realized by means of regulation valves. A CM3 pyranometer from Klipp \& Zonen was used for $G_{\text {total }}$ measurements in between the two parallel collector circuits (location marked with the green star). A copper-constantan thermocouple (TT-type) was used for measurement of the collector outlet temperature (location marked with the red star). Because of its location in Denmark (latitude: 55.89), an inclination angle of $45^{\circ}$ was chosen. The azimuth angle of the collector array was $12^{\circ}$ towards east.

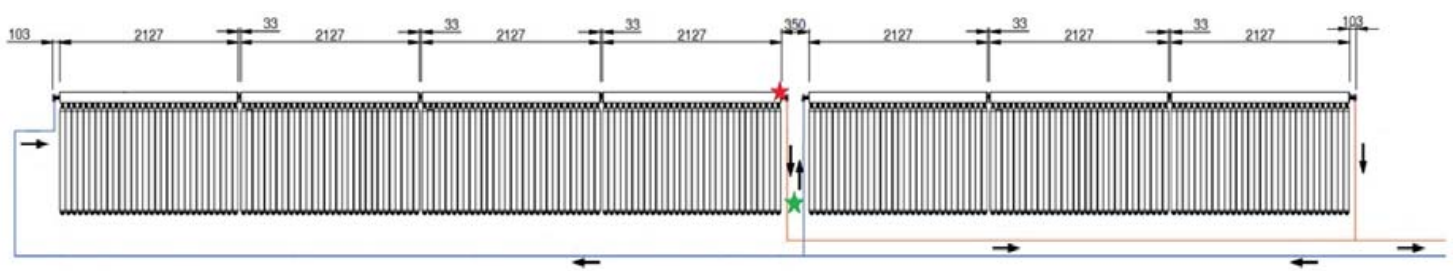

Fig. 2: Collector setup (schematic drawing).

Inside the building heat was transferred from the collector loop via a plate heat exchanger, operated in counter flow. At the secondary side, 2-way control valves were set in order to realize either buffer storage or 
PCM charge. TYFOCOR LS (propylene-glycol and water mixture) was used as solar collector fluid and water was filled in the secondary side. In Fig. 3 operation schemes for the operation modes are drawn. Active pumps and open valves are marked in green; inactive pumps and closed valves in red.

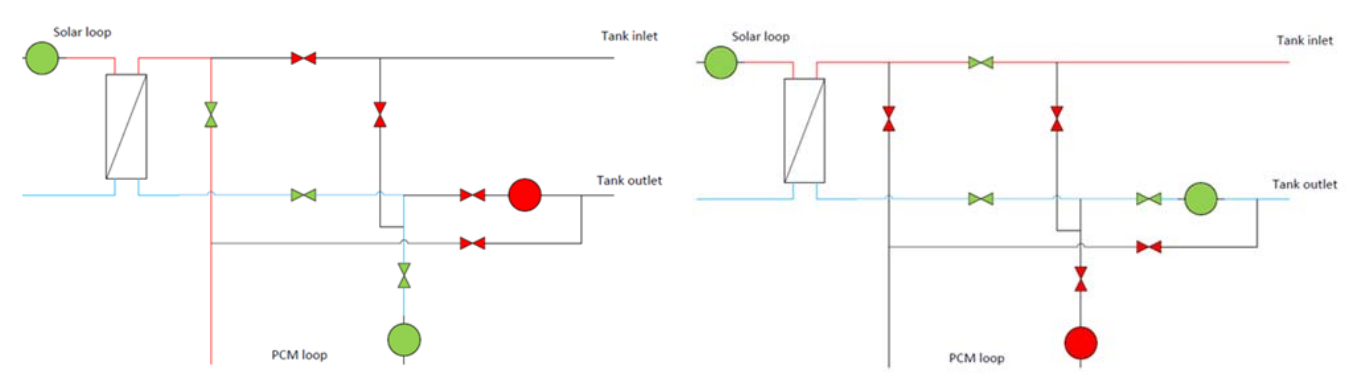

Fig. 3: Operation scheme with marked active components: PCM charge (left); buffer storage charge (right).

The forward pipe from the heat exchanger to the collector array was $21.5 \mathrm{~m}$, the return pipe was $14 \mathrm{~m} .8$ meters of the forward and of the return pipe was inside of the building of the demonstration system and the rest was outside the building. Forward and return pipe in between the heat exchanger and the water tank were both $4.5 \mathrm{~m}$ long. From the heat exchanger to the PCM heat storage units the forward pipe reached 7-9 $\mathrm{m}$ and the return pipe reached 10-12 m, depending on the number of PCM units in charge. $20 \mathrm{~mm}$ (outer diameter) copper pipes in the collector loop and 3/4" carbon steel pipes in the secondary loops were installed. Pipework, valves and the heat exchanger were insulated with $19 \mathrm{~mm}$ of elastomeric foam.

All hydraulic loops were equipped with magnetic induction flow meters (class 2) in the return flow, copperconstantan thermocouples (TT-type) for temperature measurements, thermopiles (TT-type) for temperature difference measurements and motor valves. Regarding to the norm (EN 1434), the maximum measurement error of class 2 flow sensors was $2.5 \%$ in the operation range. This accuracy was proved by tests for all flow meters installed. Electricity consumption was detected by an installed wattmeter for each pump.

\subsection{Operation sequence}

The collector loop pump was activated when the temperature difference between the collector outlet temperature and the temperature at the bottom of the water storage exceeded $10 \mathrm{~K}$ (lower threshold value). The water tank was charged until a temperature of $55^{\circ} \mathrm{C}$ was reached in the middle of the water tank. This value was chosen as the upper threshold value for the control. Buffer storage charge stopped 5 minutes after either the lower or upper threshold value was met.

When the upper threshold for the buffer storage was met, collector loop circulation stopped until a collector outlet temperature of $70^{\circ} \mathrm{C}$ was measured. Then the PCM charge mode was activated. Melting of SAT composites required higher temperature, therefore previous buffer storage charge was beneficial. In order to achieve the full melting of the PCM, which is required for stable supercooling, inlet temperatures to the PCM units of up to $93^{\circ} \mathrm{C}$ and high water flow rates were applied.

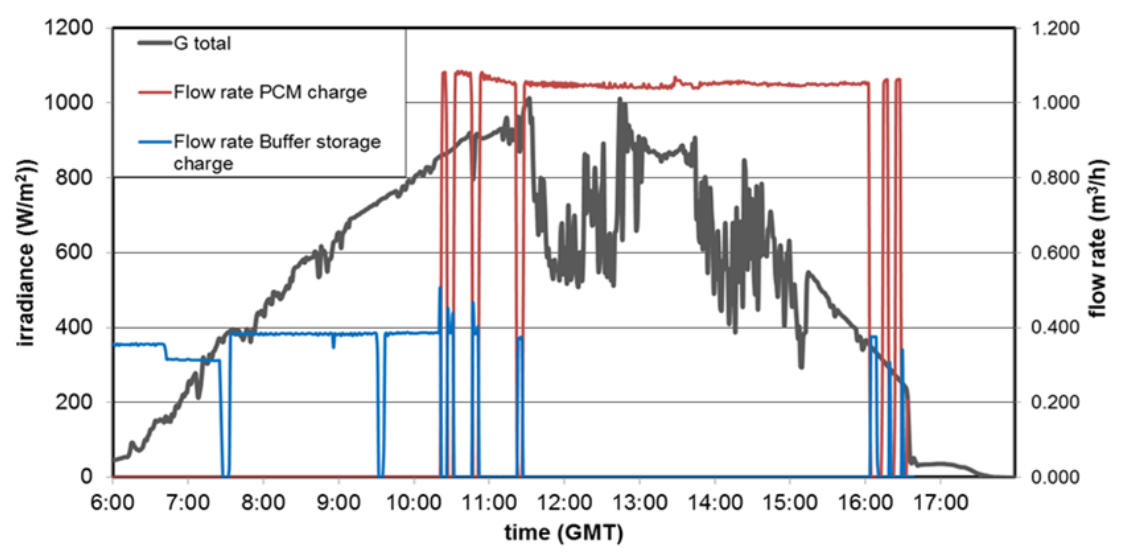


Fig. 4: Development of irradiance on the collector array and water flow rates applied.

Fig. 4 shows the flow rates applied on the secondary side of the plate heat exchanger. At 7:30 h the operation mode was switched from manual to automated control. The buffer storage was charged with a flow rate of $6.3 \mathrm{l} / \mathrm{min}$ (blue curve). Although at $10: 15 \mathrm{~h}$ the buffer storage was already heated up, some periods of additional demand around noon and in the evening were detected by the control system. The collector array was shaded from 16:20 h on. As a consequence, the operation stopped with a short delay. A water flow rate of about $16.5 \mathrm{l} / \mathrm{min}$ (red curve) was applied when the PCM storage was charged. Due to the limited heat exchange capacity rates of a single PCM unit (Englmair et al., 2016) the units were charged in parallel.

\subsection{Performance evaluation}

The evaluation was based on heat transfer rates in the charging loops. In Fig. 5 the thermopiles (TP) mark the location where the heat transfer rates were evaluated. Also inlet-and outlet temperature measurements were located there. Beside temperature difference, measured flow rates, temperature dependent densities and specific heat capacities (resulting from temperature measurements) of the heat transfer fluids (solar collector fluid and water) were used for calculation.

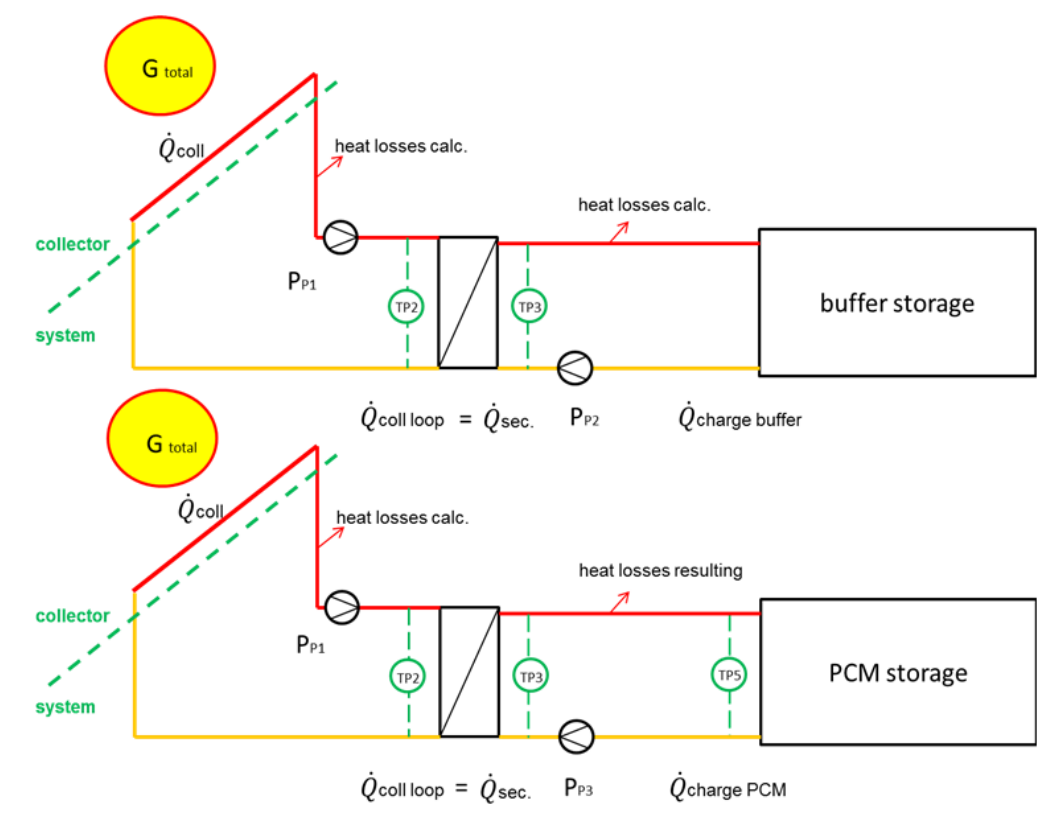

Fig. 5: Schematic evaluation model.

Pipe heat losses between the solar collector and the heat exchanger and between the heat exchanger and the buffer storage are included in the analyses. The heat loss in the solar collector loop was determined by calculations based on length, diameter and insulation thickness for the pipes and on measured temperatures. The heat loss in the PCM charge loop was resulting from the difference of heat transfer rates between TP3 and TP5. Thermal collector power was resulting from adding pipe heat losses to the calculated heat transfer rates at the plate heat exchanger.

Transferred heat was resulting from integration of heat transfer rates over time, considering the duration of each charging period.

As reference for evaluation, the solar potential was defined by the daily solar irradiation $\left(\mathrm{H}_{\text {aperture total }}\right)$ on the aperture area of the tilted collector surface. The course of the solar irradiance $\left(\mathrm{G}_{\text {total }}\right)$ is drawn in Fig. 4 (grey curve). The overall energy conversion efficiency was defined by the ratio of heat transferred to the sink ( $\left.\mathrm{Q}_{\text {charge }}\right)$ and the solar potential (formula no. 3).

$$
\begin{aligned}
& \eta_{\text {collector }}=\frac{Q_{\text {coll }}}{H_{\text {aperture total }}} \\
& \eta_{\text {system }}=\frac{Q_{\text {charge }}}{Q_{\text {coll }}}
\end{aligned}
$$




$$
\eta_{\text {overall }}=\frac{Q_{\text {charge }}}{H_{\text {aperture total }}}
$$

Energy conversion efficiency at the collector (formula no. 1) and heat transfer efficiency in the system (formula no. 2) were based on the system border to the collector array, defined in Fig. 5. This approach enabled a closer look on the dependency of heat losses to the water temperatures during the two charging modes.

In terms of electrical power, control plays a minor role in solar heating systems. Therefore the consumption of pumps (marked in Fig. 5) was evaluated with the following performance ratios:

$$
\begin{aligned}
& P R_{\text {charge buffer }}=\frac{Q_{\text {charge buffer }}}{W_{P 1 \text { charge buffer }}+W_{P 2}} \\
& P R_{\text {charge } P C M}=\frac{Q_{\text {charge } P C M}}{W_{P 1 \text { charge } P C M}+W_{P 3}} \\
& P R_{\text {charge overall }}=\frac{Q_{\text {charge buffer }}+Q_{\text {charge } P C M}}{W_{P 1}+W_{P 2}+W_{P 3}}
\end{aligned}
$$

As reference, their electrical work was logged during charging periods (indicated by the flow rates in Fig. 4). The collector loop pump (P1) was in operation during all periods, while P2 operated during buffer storage charge and P3 during PCM storage charge.

\section{Results and discussion}

On the selected day, the system was only in charging operation. Heat transfer rates, the daily energy balance as well as efficiency values were evaluated.

\subsection{Heat transfer rates}

In Fig. 6 the development of heat transfer rates of the collector loop (black marks), of the buffer storage charge loop (blue marks) as well as of the PCM charge loop (red marks) are drawn over time. The collector loop power followed $G_{\text {total }}$ (grey curve in Fig. 4). During PCM charge peak values of up to $19 \mathrm{~kW}$ were reached when the mode has been activated (10:15 h), as well as during cascading of the number of PCM units $(13: 30 \mathrm{~h}-14: 00 \mathrm{~h})$ in the charging loop.

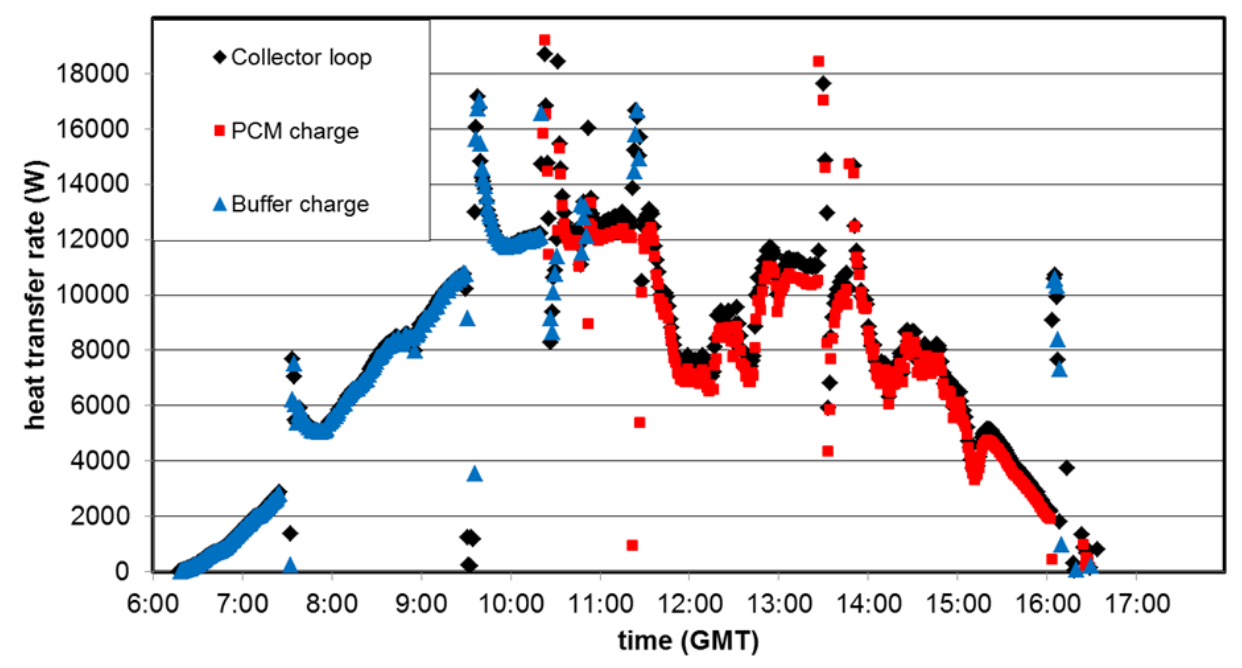

Fig. 6: Heat transfer rates during the course of the day.

Because the buffer storage is situated close to the plate heat exchanger, the collector loop power almost equaled to the heat transferred to the water tank. Buffer storage charge was interrupted two times before noon. Significant heat losses occurred in the PCM charge loop. The total duration of heat transfer was 10 hours.

The data were noisy through to the setting of the control system. Cascading of PCM units during PCM storage charge is necessary to match the fluctuating collector power with the limited heat transfer capacity of 
PCM units. In contrast, intermediate buffer storage charge during periods of PCM storage charge only happened due to small internal temperature changes in the water tank. This cooled down the collector array and system components (collector loop, plate heat exchanger, pipework). Therefore a temperature hysteresis for full buffer charge (end criterion: $60^{\circ} \mathrm{C}$, start criterion: $50^{\circ} \mathrm{C}$ ) was implemented in the control after the present initial tests.

\subsection{Daily energy balance}

The energy balance was analyzed by integration of the heat transfer rates over time. Fig. 7 shows the solar potential (black curve) compared to the transferred heat during the course of the day. The difference between the collector loop energy (red curve) and the calculated collector output (red dotted curve) was a result of the pipe heat losses in the collector loop. During the total period of operation, the solar potential was $135 \mathrm{kWh}$. From this potential $79 \mathrm{kWh}$ of energy was supplied by the collector loop to the heat storage system. $76 \mathrm{kWh}$ ( $53 \%$ of the solar potential) of heat was stored. Most heat was transferred to the PCM modules (46 kWh) in the period from 10:30 $\mathrm{h}$ to $16: 00 \mathrm{~h}$. This means an average net heat transfer rate of $9 \mathrm{~kW}$. To the buffer tank (green curve) the highest share of energy $(25 \mathrm{kWh})$ was transferred until 10:00 $\mathrm{h}$, while the rest was transferred later, in four short periods.

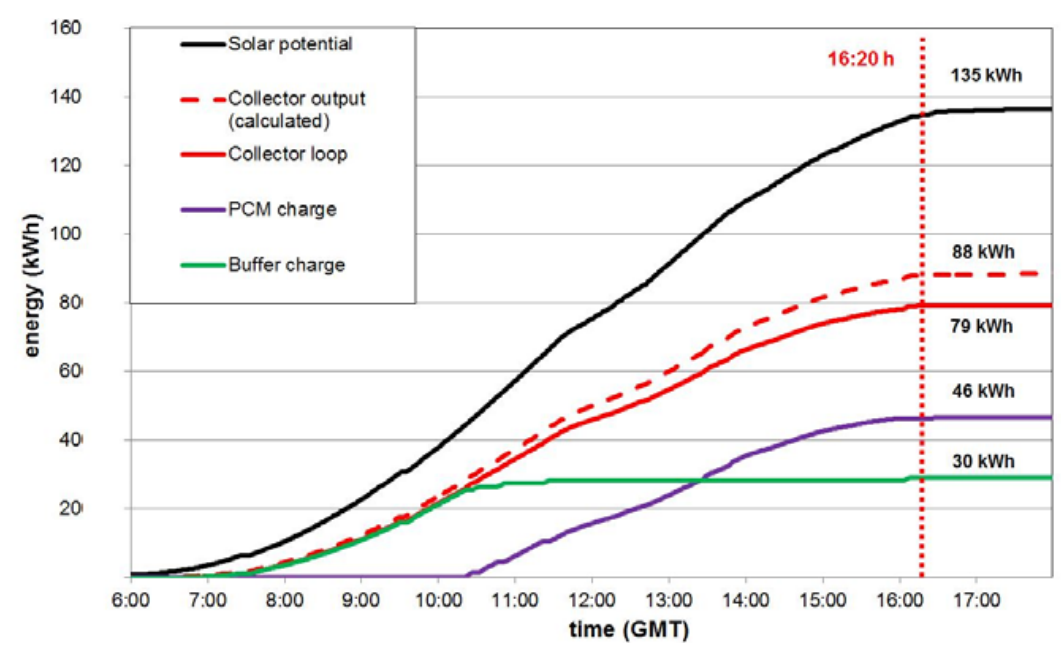

Fig. 7: Development of heat transfer during the course of the day.

During buffer storage charge only minor heat losses occurred in the system (collector loop and charging loop), while significant heat losses $(8 \mathrm{kWh})$ occurred during the charge of the PCM units with high solar collector fluid and water temperatures.

The buffer storage charge means an average temperature increase of $35 \mathrm{~K}$ in the water tank (750 1), which was considered to be sufficiently high to cover the heat demand of an energy efficient single family house throughout the following day. Full charge of a single PCM unit (from solid state at ambient temperature) required $27.4 \mathrm{kWh}$ (Englmair et al., 2016). However, since up to 3 PCM units were charged in parallel, 2 consecutive sunny days are assumed to be necessary to ensure full PCM unit heat up to a uniform temperature of $80^{\circ} \mathrm{C}$. Only in this way the supercooling ability of charged PCM units can be enabled.

\subsection{Energy efficiency}

Based on the daily energy balance, average energy efficiency factors are obtained:

$$
\eta_{\text {collector }}=0.65 ; \quad \eta_{\text {system }}=0.86 ; \quad \eta_{\text {overall }}=0.56
$$

As a result of energy conversion of the collector, $65 \%$ of the solar potential was transferred in form of heat to the system. The system efficiency was $86 \%$ on the reference day. $10 \%$ of heat in the collector loop and 4 $\%$ of heat in the secondary loop were dissipated via heat losses to the ambience. So, in total $56 \%$ of the solar potential was transferred to the heat sink.

Further information can be seen from the course of energy efficiencies in context to the collector outlet temperature in Fig. 8. The energy conversion efficiency at the collector (grey scattered curve) was low until 
9:00 h. During this period and all components of the collector loop as well as the heat transfer fluids were heating up. Peak values occurred due to changes of operation modes. After 9:00 h $\eta_{\text {collector }}$ reached a level of above $65 \%$. Because of rising heat transfer fluid temperatures (indicated by the collector outlet temperature - red curve) $\eta_{\text {collector }}$ fell throughout the day. Shifts between buffer and PCM charge modes (Fig. 4) caused collector outlet temperature jumps. During PCM charge the heat transfer fluid temperatures were coupled to the state of PCM unit charge.

After 15:00 $\mathrm{G}_{\text {total }}$ and the efficiency values fell down dramatically and the heat transfer fluid temperatures remained high. When the operation stopped, heat remained in the hot heat transfer loops and in the solar collector.

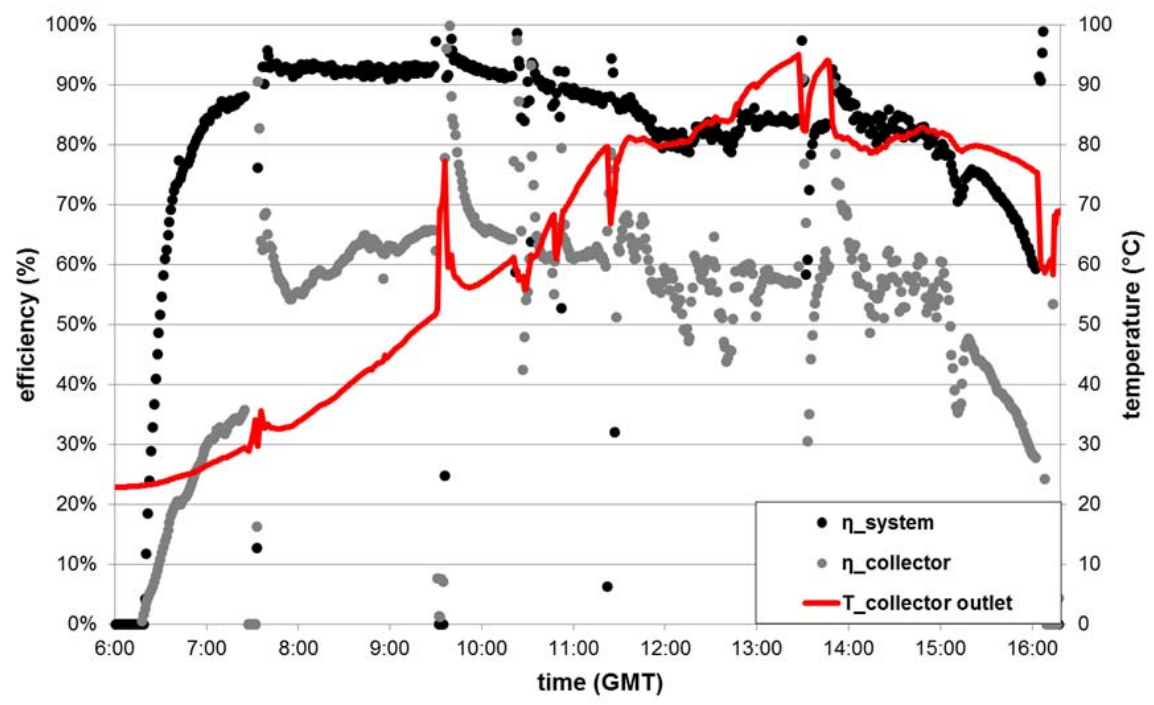

Fig. 8: Development of system efficiency, energy conversion efficiency at the collector and collector outlet temperature during the course of the day.

The system efficiency (black scattered curve) showed similar behavior. After the pipework was heated up (until 7:30 h), $\eta_{\text {system }}$ remained above $90 \%$ during buffer storage charge. During PCM charge, when heat transfer fluid temperatures raised and a longer pipework was used, $\eta_{\text {system }}$ was in the range of 80-90\% for long time. Lower values were observed around noon, when $\mathrm{G}_{\text {total }}$ was fluctuating at lower level than before noon. Decreasing system efficiency after 15:00 h was a result of lower heat transfer rates at high fluid temperatures. This means that during that period a high share of heat was dissipated to the ambience.

Longer periods of buffer storage charge (lower heat transfer fluid temperatures) at the end of the day (when $\mathrm{G}_{\text {total }}$ is decreasing) would maximize the daily energy yield. Increased $\eta_{\text {system }}$ and $\eta_{\text {collector }}$ values would be resulting. However, PCM unit charge is beneficial after the buffer heat storage is sufficiently heated for domestic heating applications.

\subsection{Pump efficiency}

The secondary loop pump (P2) was powered with $8 \mathrm{~W}$ to achieve the set water flow rate during buffer charge. To match the heat transfer capacity rate of the solar collector fluid at the heat exchanger to the water, a collector loop pump power of $70 \mathrm{~W}$ was required. During PCM charge the pumps were set at $90 \%$ of their maximum operation speed to enable high fluid flow rates. The collector loop pump power reached $390 \mathrm{~W}$ and the secondary loop pump (P3) was operating at $120 \mathrm{~W}$. The resulting electricity consumptions are given in Tab. 1:

\begin{tabular}{|l|c|c|c|}
\hline & WP1 & WP2 & WP3 \\
\cline { 2 - 4 } & $($ Wh $)$ & $($ Wh $)$ & (Wh) \\
\hline Buffer charge & 167 & 22 & none \\
\hline PCM charge & 1716 & none & 548 \\
\hline Overall charge & 1883 & 22 & 548 \\
\hline
\end{tabular}

Tab. 1: Pump electricity consumption during charging periods. 
The electrical power consumption of pumps during PCM charge (about 5 hours of operation) was $2.5 \mathrm{kWh}$, while for buffer storage charge only $0.2 \mathrm{kWh}$ were consumed. Based on the previous definitions, the following performance ratios were resulting:

$$
P R_{\text {charge buffer }}=154 ; \quad P R_{\text {charge } P C M}=19.1 ; \quad P R_{\text {charge overall }}=30.8
$$

The highest performance ratio was occurring during buffer storage charge (154), while the performance ratio during PCM module charge was about 8 times lower. The overall charge performance ratio was 30.8. It was found that the electricity consumption for PCM charge can be lowered by application of different pump types. Also, a reduction of flow rates during PCM charge could lower the electricity consumption. However, this would lower the heat transfer in the PCM units.

\section{Conclusions}

A demonstration system on seasonal heat storage, utilizing the principle of stable supercooling of SAT, was tested for its functionality during charge on a representative sunny day. System control enabled interplay between solar collectors, buffer heat storage and PCM heat storage:

- The applied collector array enabled sufficiently high heat transfer for both, buffer storage and PCM charge. The heat transfer reached peak values of more then $12 \mathrm{~kW}$ in both operation modes. When modes were changed or interrupted, heat transfer rates of up to $19 \mathrm{~kW}$ occurred.

- During PCM charge the HTF temperatures were increasing with the state of PCM charge. This is in contrast to maximisation of solar yield. Since the number of PCM units in operation was variable, no restrictions for heat transfer from the collector array were observed.

- Regarding to the required high collector outlet temperatures (up to $95^{\circ} \mathrm{C}$ ) during PCM charge, the energy conversion efficiency of the collector array was satisfying. $65 \%$ of the solar potential was converted into heat and transferred to the system.

- $76 \mathrm{kWh}(86 \%)$ of available heat was stored. During buffer storage charge only minor pipe heat losses occurred. $46 \mathrm{kWh}$ of heat were charged to the PCM storage when $8 \mathrm{kWh}(10 \%$ of available heat) were dissipated via hydraulic components to the ambience.

- $\quad$ The PCM charge performance ratio (19.1) and therefore also the overall performance ratio (30.8) were quite low, although standby consumptions of pumps and of the control system were not considered in their calculation.

The resulting operation sequence proved functional system behavior. Significant heat losses due to a long pipework, frequent mode-switches and rather high pump electricity consumption during PCM charge were identified as areas for potential improvements.

\section{Acknowledgements}

This research was funded by the European Commission (Grant Agreement N_295568) as part of the Seventh Framework Programme through the former COMTES project. The work was also supported by the $\mathrm{PhD}$ program of the Sino Danish Center for Education and Research (SDC). We thank our partners from Nilan $\mathrm{A} / \mathrm{S}$ and the Graz University of Technology for sharing knowledge and discussions as well as the research technicians Troels V. Kristensen and Claus Aagaard for their practical support.

\section{References}

Dannemand, M., Dragsted, J., Fan, J., Johansen, J. B., Kong, W., \& Furbo, S., 2016. Experimental investigations on prototype heat storage units utilizing stable supercooling of sodium acetate trihydrate mixtures. Applied Energy, 169, 72-80.

Dannemand, M., Schultz, J. M., Johansen, J. B., \& Furbo, S., 2015. Long term thermal energy storage with stable supercooled sodium acetate trihydrate. Applied Thermal Engineering, 91, 671-678. 
Englmair, G., Dannemand, M., Johansen, J. B., Kong, W., Dragsted, J., Furbo, S., \& Fan, J., 2016. Testing of PCM Heat Storage Modules with Solar Collectors as Heat Source. Energy Procedia, 91, 138-144.

Kong, W., Dannemand, M., Johansen, J. B., Fan, J., Dragsted, J., Englmair, G., \& Furbo, S., 2016. Experimental investigations on heat content of supercooled sodium acetate trihydrate by a simple heat loss method. Solar Energy, 139, 249-257.

Meisingset, K. K., \& Grønvold, F., 1984. Thermodynamic properties and phase transitions of salt hydrates between 270 and $400 \mathrm{~K}$ III. CH3CO2Na·3H2O, CH3CO2Li·2H2O, and (CH3CO2)2Mg·4H2O. The Journal of Chemical Thermodynamics, 16(6), 523-536. 